Chemotheraphy 1988;34(Suppl. 1):I-III

\title{
Contents, Supplement 1, 1988
}

\section{Contents}

Introduction

Fraschini, F 1

Bactericidal Effect of Ceftriaxone versus Imipenem plus Cilastatin in Bronchial Secretion

Fraschini, F.; Scaglione, F.; Cogo, R.; Casali, W.; Falchi, M.; Gattei, G 3

Ceftriaxone Alone Compared to Ampicillin and Chloramphenicol in the Treatment of

Bacterial Meningitis

Girgis, N.I.; Abu El-Ella, A.H.; Farid, Z.; Haberberger, R.L.; Woody, J.N 16

Comparative Study of Ceftriaxone Monotherapy versus a Combination Regimen of

Cefuroxime plus Gentamicin for Treatment of Serious Bacterial Infections:

The Efficacy, Safety and Effect on Fecal Flora

Hoepelman, I.M.; Rozenberg-Arska, M.; Verhoef, J 21

Comparative Study of Ceftriaxone and Cefoperazone in the Treatment of Acute

Cholecystitis

Friedlender, J.; Meyer, P.; Marti, M.C.; Rohner, A 30

Short-Term Treatment of Streptococcal Tonsillitis with Ceftriaxone

Pavesio, D.; Pecco, P.; Peisino, M.G 34

Single Intramuscular Dose of Ceftriaxone as Compared to 7-Day Amoxicillin Therapy for Acute Otitis Media in Children. A Double-Blind Clinical Trial

Varsano, I.; Frydman, M.; Amir, J.; Alpert, G

Ceftriaxone in the Treatment of Bacterial Meningitis in Adults

Zavala, I.; Barrera, E.; Nava, A

Ceftriaxone Penetration of Tissues

Billstein, S.A 53

Author Index 59

Subject Index 60 